Check for updates

Cite this: RSC Adv., 2019, 9, 22389

\title{
Cyclic voltammetry growth and characterization of Sn-Ag alloys of different nanomorphologies and compositions for efficient hydrogen evolution in alkaline solutions
}

\author{
Mohamed Shaban, (D)*a Islam Kholidy, ${ }^{\text {ab }}$ Ghada M. Ahmed, ${ }^{c}$ Mosaad Negem (D) \\ and Hanafy M. Abd El-Salam ${ }^{\text {b }}$
}

Electrodeposition of silver, tin and their alloys from different aqueous electrolytes suffer from various environmental issues and deposits are affected by $\mathrm{H}_{2}$ evolution and metal oxide formation. In this work, these metals and their alloys are electrodeposited by cyclic voltammetry utilizing ionic liquids based on $\mathrm{C}_{5} \mathrm{H}_{14} \mathrm{ClNO}$ (choline chloride) that permits deposit properties control. Both $\mathrm{Ag}$ and $\mathrm{Sn}$ concentrations in the ionic liquid were varied from 0.01 to $0.15 \mathrm{~mol} \mathrm{~L}^{-1}$. Methionine effect on the reduction potential of $\mathrm{Sn}$ and Ag was studied. Different techniques were applied to explore the structures, morphologies, and electrochemical (EC) activities of the deposits. A single $\mathrm{Ag}_{3} \mathrm{Sn}$ phase with orthorhombic packed structure was observed for all alloys, whereas the preferred growth orientation was varied from (202) to (112) depending on $\mathrm{Ag} \%$. Also, the dislocation density is decreased by increasing Ag content. EDX spectra showed only $\mathrm{Ag}$ and $\mathrm{Sn}$ signals indicating the high purity of the $\mathrm{Sn}-\mathrm{Ag}$ alloys. The deposit from $\mathrm{Sn}$-rich liquid showed rougher and larger agglomerates at the surface than that formed from the Ag-rich liquids with or without methionine. The electrochemical activities of the deposits toward the $\mathrm{H}_{2}$ evolution reaction (HER) were investigated through electrochemical polarization (ECP) measurements and EC impedance spectroscopies (EISs). The Sn-Ag alloys possess higher performance, as a catalyst for HER using alkaline solution, than $\mathrm{Ag}$ or $\mathrm{Sn}$ electrodes. The highest rate of HER was recorded for $\mathrm{Sn}-35 \% \mathrm{Ag}$ and $\mathrm{Sn}-97 \% \mathrm{Ag}$ deposits, which correlated strongly to the microstructure and surface morphology. The ECP results were confirmed by EIS investigations. The measured impedance values are close-fitting to a hypothetical model for the electrode/electrolyte interface.

Received 10th May 2019 Accepted 15th July 2019

DOI: 10.1039/c9ra03503f

rsc.li/rsc-advances constituent metals or/and variation of deposition kinetics of one metal relative to the other one. Many studies have been focused on imidazolium cations with distinct anionic species, for example, $\left(\mathrm{F}_{3} \mathrm{CSO}_{2}\right)_{2} \mathrm{~N}, \mathrm{PF}_{6}$ and $\mathrm{BF}_{4} \cdot{ }^{2}$ The resultant ionic liquids (ILs) showed relative high conductivity and low viscosity. Also, ILs can be obtained using a simple quaternary $\mathrm{NH}_{4}{ }^{+}$cation and complexing the anion to reduce the freezing point and delocalize the charge effectively. Eutectic based ILs are presented by a general formula as $\mathrm{R}_{1} \mathrm{R}_{2} \mathrm{R}_{3} \mathrm{R}_{4} \mathrm{~N}^{+} \mathrm{XzY} .^{3}$ The cation $\mathrm{R}_{1} \mathrm{R}_{2} \mathrm{R}_{3} \mathrm{R}_{4} \mathrm{~N}^{+}$is a quaternary ammonium salt like choline, ammonium, phosphonium, sulphonium. $\mathrm{X}$ represents the $\mathrm{Cl}^{-}$ halide. ${ }^{4,5} \mathrm{Y}$ is a complexing agent and $z$ represents the quantitative number of required molecules. These kinds of ILs are classified into three categories ${ }^{2}$ based on $\mathrm{Y}: \mathrm{Y}=\mathrm{MCl}_{x}, \mathrm{M}=\mathrm{Zn}$, Fe, Sn, Al, or Ge for category (a); $\mathrm{Y}=\mathrm{MCl}_{x} \cdot y \mathrm{H}_{2} \mathrm{O}$ for category (b); and $\mathrm{Y}=\mathrm{RZ}, \mathrm{Z}=\mathrm{CONH}_{2}$ or $\mathrm{COOH}$ or $\mathrm{OH}$ for category (c). The preparation of this kind is the simplest among all kinds of ILs, and is achieved by mixing two components with gentle heating through a mild endothermic reaction. ${ }^{3,4}$ The physical/ electrochemical properties and speciation happening in 
categories (a) and (b) are widely addressed; where the ILs have been addressed for various metals. Whereas, limited investigations were accomplished utilizing category (c). Deep eutectic solvents have been created utilizing alcohols and acidic complexing agents for polymerization, electro-polishing, and electro-deposition. ${ }^{2}$ Many previous reports were focused on $\mathrm{C}_{5} \mathrm{H}_{14} \mathrm{ClNO}$ as a cationic ammonium salt because of its nontoxicity, biodegradability, and applicability in many household and industrial applications. ${ }^{2}$ Therefore, it could be implemented for extensive production in a cost-effective way. Here, we demonstrate how DESs are formed utilizing $\mathrm{C}_{5} \mathrm{H}_{14} \mathrm{ClNO}$ and $\left(\mathrm{CH}_{2} \mathrm{OH}\right)_{2}$ (1,2-ethanediol) and how they can be applied for the electro-deposition of $\mathrm{Ag}, \mathrm{Sn}$, and $\mathrm{Ag} / \mathrm{Sn}$ alloys. Also, we studied the effect of selecting the H-bond donors upon the alloy type and solution constituents' electrochemistry. Here, silver is chosen as an element to be alloyed with tin because it possesses a high melting point and low contact resistance. Also, the $\mathrm{Ag} / \mathrm{Sn}$ alloy is very essential constituent for designing hightemperature automotive connectors and for soldiers after the restrictions on the usage of $\mathrm{Pb}^{6}$ Also, $\mathrm{Sn}$ and $\mathrm{Ag}$ metals can produce hydrogen energy using different techniques. The Ag deposition on $\mathrm{Cu}$ foil occurred from silver chloride $(\mathrm{AgCl})$ soluble in ionic liquid under light illumination without the application of any potential. i.e., $\mathrm{AgCl}$ is a photosensitive chemical which decomposed into dark silver powder and chlorine under light illumination. So, black conical was used during the electrodeposition of silver-based alloys. The main objective of this study is to identify the optimal conditions for electrodepositing high-quality $\mathrm{Ag} / \mathrm{Sn}$ alloys with different contents of silver and tin from nontoxic ILs. It is also the first stage of characterization of the obtained silver-tin alloys with outstanding nano-features. Also, for the first time, methionine is used as a novel additive to decrease the reduction potential of silver and tin slightly.

On the other hand, renewable energy, such as photovoltaic cells, faces a storage problem that urges the generation of suitable fuel for efficient transportation and usage. Competent hydrogen can be considered the most competitive competitor, the largest plentiful element on Earth, to substitute fossil fuels for use in many applications. ${ }^{20}$ The advance of efficient catalysts for hydrogen evolution reactions (HERs) in basic electrolytes remnants the main practical obstacle to improve the water electrolyzers, fuel cells, and other industrial devices for electrochemical energy conversion and storage. Depend on the free energy of adsorbed hydrogen intermediates; theoretically, it is highly expected that alloys of tin and silver are active for these reactions. $^{20}$ Consequently, we synthesized binary nanocrystalline $\mathrm{Sn} / \mathrm{Ag}$ alloys of different morphologies and $\mathrm{Sn} / \mathrm{Ag}$ ratios and showed that the optimum Sn/Ag alloys are actually more effective than individual constituents ( $\mathrm{Sn}$ or $\mathrm{Ag}$ ) for electrochemical HERs. Also, we showed the impact of using novel additive (methionine) on Sn/Ag alloy and its effect on HER and impedance. Methionine is a sulfur-containing proteinogenic amino acid $\left(\mathrm{C}_{5} \mathrm{H}_{11} \mathrm{NO}_{2} \mathrm{~S}\right)$ with high solubility in water $(53.7 \mathrm{~g} / 1 \mathrm{~L}$ (a) $\left(20^{\circ} \mathrm{C}\right)$ ), low melting point $\left(281^{\circ} \mathrm{C}\right)$, and reversible oxidation state. $^{21}$ Methionines is acting as an intermediate in the biosynthesis of different phospholipids, is important in the single-carbon metabolism, and can be easily obtained from food (vertebrate and plant sources) and used as supplier of sulfur and a few other compounds. Methionine may act as a redox sensor and can be used as a nontoxic pesticide option against giant swallowtail caterpillars. ${ }^{22,23} \mathrm{Li}$ et al. used methionine as an eco-friendly corrosion inhibitor for $\mathrm{Cu}-\mathrm{Ni}$ alloy. ${ }^{24}$ Additionally, we carried the electrochemical polarization (ECP) measurements and EC impedance spectroscopies (EISs) to evaluate the electrochemical activities of the deposits toward HERs. $^{25}$

\section{Experimental details}

\subsection{Chemicals}

$\mathrm{C}_{5} \mathrm{H}_{14} \mathrm{ClNO}$ [Choline Chloride; ChCl] (Sigma Aldrich 99\%) was formed using absolute $\mathrm{C}_{2} \mathrm{H}_{5} \mathrm{OH}$ [ethanol] after filtration and drying under vacuum. $\left(\mathrm{CH}_{2} \mathrm{OH}\right)_{2}$ [ethylene glycol; EG; > 99\%], silver chloride $(>99 \%)$, tin chloride $(\geq 99 \%)$, and methionine were obtained from Sigma-Aldrich. Also, alumina paste (Shandong Luxin Mount Tai Co., China) and dichloromethane (Merck, Darmstadt, Germany) were used.

\subsection{Ionic liquid preparation}

Mixtures were prepared by mixing up the $\mathrm{C}_{5} \mathrm{H}_{14} \mathrm{ClNO}$ and $\left(\mathrm{CH}_{2} \mathrm{OH}\right)_{2}$ together at molar ratio $1: 2$ using magnetic stirring at $100{ }^{\circ} \mathrm{C}$ looking forward a colorless identical liquid formation. The prepared ionic liquid was kept at $30^{\circ} \mathrm{C}$.

\subsection{Electro-deposition of $\mathrm{Sn}, \mathrm{Ag}$, and $\mathrm{Sn} / \mathrm{Ag}$ alloys}

The cyclic voltammetry deposition was carried out using Voltalab potentiostat (Model PGZ 100). A three-electrode cell was designed for the electro-deposition experiments. This cell is consisting of $0.5 \mathrm{~mm}$ diameter Pt electrode, Pt counter electrode, and $\mathrm{Ag}$ wire reference electrode. $0.3 \mathrm{ml} \mathrm{Al}{ }_{2} \mathrm{O}_{3}$ paste is used to polish the working electrode. After that, the working electrode is rinsed and dried before usage. All voltammograms are measured at a scanning rate of $50 \mathrm{mV} \mathrm{s}^{-1}$ and temperature $40{ }^{\circ} \mathrm{C} .{ }^{1,2,9}$ Hull cell panels had been prearranged by cleaning with deionized $\mathrm{H}_{2} \mathrm{O}$ and drying, degreased in dichloromethane (DCM) for two minutes, then removed and dried. The cell is filled with $1: 2 \mathrm{C}_{5} \mathrm{H}_{14} \mathrm{ClNO}:\left(\mathrm{CH}_{2} \mathrm{OH}\right)_{2}$ ionic liquid containing $\mathrm{Ag}$ ion (0.05-0.15 $\left.\mathrm{mol} \mathrm{L}^{-1}\right)$ and $\mathrm{Sn}$ ion $\left(0.03-0.075 \mathrm{~mol} \mathrm{~L}^{-1}\right)$. The plating experiments were performed by the potentiostatic and galvanostatic method. For deposition by the potentiostatic method, the potentiostat was used for maintaining the specific potential during deposition experiments. For galvanostatic deposition, adjustable power supply (Thurlby-Thandar) and digital fluke multimeter were used.

\subsection{Samples characterization}

The surfaces of deposited alloys were imaged using scanning electron microscope (SEM, Quanta 250 FEG (FEI Company, Eindhoven, Holland)), and chemicals compositions were quantitatively examined using the accompanied energy dispersive X-ray unit (EDX). X-ray diffraction charts for the deposited alloys are assessed utilizing X-ray diffractometer with X-ray 
generator (Phillips model PW 1730), diffractometer (PW 1716) and detector (PW 1050/25). $\mathrm{Cu}\left(\lambda_{\mathrm{K} \alpha}=0.154 \mathrm{~cm}^{-1}\right)$ was used as an anode at $40 \mathrm{kV}$ accelerating voltage, $35 \mathrm{~mA}$ current, $0.02^{\circ}$ scanning rate within angle ranged from 10 to $90^{\circ}$.

\section{Results and discussion}

\subsection{Electrochemical measurements}

3.1.1. Deposition of tin. The cyclic voltammetry plots were measured with a scan rate $50 \mathrm{mV} \mathrm{s}^{-1}$ and potential range -2 to $+2 \mathrm{~V}$ using the electroplating baths of $\mathrm{SnCl}_{2}$ to identify the appropriate current and potential for electroplating of Sn. A double jacket cell provided with Pt electrodes as working and countering electrodes and a saturated calomel electrode as a reference electrode was used. The solvent was an ionic liquid of $\mathrm{C}_{5} \mathrm{H}_{14} \mathrm{ClNO}$ and $\left(\mathrm{CH}_{2} \mathrm{OH}\right)_{2}(1: 2)$. Fig. 1 (a) shows cyclic voltammetry curves using $\mathrm{SnCl}_{2}$ solutions of concentrations $0.03,0.05$ and $0.075 \mathrm{~mol} \mathrm{~L}^{-1}$. The cathodic and anodic current peaks were detected. As shown, the reduction process of $\operatorname{tin}(\mathrm{Sn})$ started at $-0.682 \mathrm{~V}$ and reaching the maximum value at peak of cathodic potential $\left(E_{\mathrm{pc}}\right)$ equal $-789,-760$, and $-857 \mathrm{mV}$ using concentrations $0.03,0.05$ and $0.075 \mathrm{~mol} \mathrm{~L}^{-1}$, respectively. The height of the cathodic current peak and anodic current peaks is increased with increasing $\mathrm{SnCl}_{2}$ concentration. The peak cathodic current densities $\left(I_{\mathrm{pc}}\right)$ were $-2.78,-4.77$, and $-24.77 \mathrm{~mA} \mathrm{~cm}{ }^{-2}$, respectively. On the contrary sweep, two oxidation peaks are observed. The values of peak anodic current densities were 3.788, 13.672, and $30.563 \mathrm{~mA} \mathrm{~cm}^{-2}$ for $I_{\mathrm{pa} 1}$ and $1.481,5.731$, and $6.016 \mathrm{~mA} \mathrm{~cm}^{-2}$ for $I_{\mathrm{pa} 2}$ at concentrations $0.03,0.05$ and $0.075 \mathrm{~mol} \mathrm{~L}^{-1}$, respectively. The values of peak 1 anodic potential $\left(E_{\mathrm{pa} 1}\right)$ were -537 , -506 , and $-463 \mathrm{mV}$, respectively. The full-width half-maximum (FWHM) of cathodic peaks were 152, 101, and $152 \mathrm{mV}$, respectively. FWHM values for anodic peak 1 were 87,120 , and $131 \mathrm{mV}$ at concentrations $0.03,0.05$ and $0.075 \mathrm{~mol} \mathrm{~L}^{-1}$, respectively. Therefore, a single reduction peak was observed due to the reduction of $\mathrm{Sn}^{2+}$ to $\mathrm{Sn}^{0}$ and two oxidation peaks rising from the oxidization back of metal to $\mathrm{Sn}^{2+}$. This agrees well with the work that carried out by other researchers. ${ }^{10}$ This was not likely to be the reaction scheme for the formation of $\mathrm{Sn}^{4+}$ to $\mathrm{Sn}^{2+}$ as stated above. ${ }^{11}$ This reaction is likely to occur in basic electrolyte because $\mathrm{Sn}^{4+}$ with six chloride complex is not stable in an acidic electrolyte.

3.1.2. Deposition of silver. Electroplating baths of $\mathrm{AgCl}$ were used for the deposit of $\mathrm{Ag}$ using cyclic voltammetry at $50 \mathrm{mV} \mathrm{s}^{-1}$ scanning rate and potential ranged from -2 to $+2 \mathrm{~V}$ to determine the appropriate current and potential for electroplating. The used concentrations of $\mathrm{AgCl}$ were $0.05,0.1$ and $0.15 \mathrm{~mol} \mathrm{~L}^{-1}$. The voltammograms in Fig. 1(b) showed a single reduction peak which was due to the reduction of $\mathrm{Ag}^{+}$to $\mathrm{Ag}^{0}$ and peak rising from the oxidation back of metal to $\mathrm{Ag}^{+}$. The reduction peak was observed at $-235,-248$, and $-307 \mathrm{mV}$ with $I_{\mathrm{pc}}$ of $-8.64,-12.39$, and $-18.75 \mathrm{~mA} \mathrm{~cm}^{-2}$ and FWHM of 129.7, 130.6, and $133.2 \mathrm{mV}$ at $\mathrm{AgCl}$ concentrations of $0.05,0.1$ and $0.15 \mathrm{~mol} \mathrm{~L}^{-1}$, respectively. i.e., the reduction potential, current density, and FWHM are increased by increasing $\mathrm{AgCl}$ concentration. Also, the oxidation peak is observed at 1,55 , and $73 \mathrm{mV}$ with $I_{\mathrm{pa}}$ of $16.83,26.81$, and $30.45 \mathrm{~mA} \mathrm{~cm}^{-2}$ and FWHM of 112.4, 126.2 , and $133.2 \mathrm{mV}$ at $\mathrm{AgCl}$ concentrations of $0.05,0.1$ and $0.15 \mathrm{~mol} \mathrm{~L}^{-1}$, respectively. Then, the height of the anodic current peak increased with increasing $\mathrm{AgCl}$ concentration.

3.1.3. Influence of methionine on the reduction potential of Sn. Fig. 2(a) displays the influence of methionine $\left(\mathrm{C}_{5} \mathrm{H}_{11} \mathrm{NO}_{2} \mathrm{~S}\right)$ on the reduction potential of $\mathrm{Sn}$. In the absence of methionine, the reduction of $\mathrm{Sn}^{2+}$ to $\mathrm{Sn}^{0}$ starts to take place at about $-674 \mathrm{mV}$. The position of the reduction peak is reduced from $-857 \mathrm{mV}$ to $-816 \mathrm{mV}$ and its current density is decreased from -24.77 to $-20.67 \mathrm{~mA} \mathrm{~cm}{ }^{-2}$ with the addition of $0.003 \mathrm{~mol} \mathrm{~L}^{-1}$ methionine. By increasing the concentration of methionine to $0.075 \mathrm{~mol} \mathrm{~L}^{-1}$, the reduction peak potential is shifted to $-737 \mathrm{mV}$ with $I_{\mathrm{pc}}=-8.67 \mathrm{~mA} \mathrm{~cm}{ }^{-2}$, a change of $120 \mathrm{mV}$ to a more positive potential. Methionine is an $\alpha$-amino acid which contains an $\alpha$-amino group (which is in the protonated $-\mathrm{NH}_{3}{ }^{+}$form), an $\alpha$-carboxylic acid group (which is in the deprotonated $-\mathrm{COO}^{-}$form), and an $S$-methyl thioether side chain (which is nonpolar). So, the simplicity of $\mathrm{Sn}^{2+}$ reduction to Sn may be ascribed to inner-electron transfer depending upon the existence of electron-rich groups such as a carboxylate, or unpaired electrons that might be found in methionine sulfur. Then, the effect of neighboring group participation in the reduction is significant in $\mathrm{Sn} /$ methionine complex.
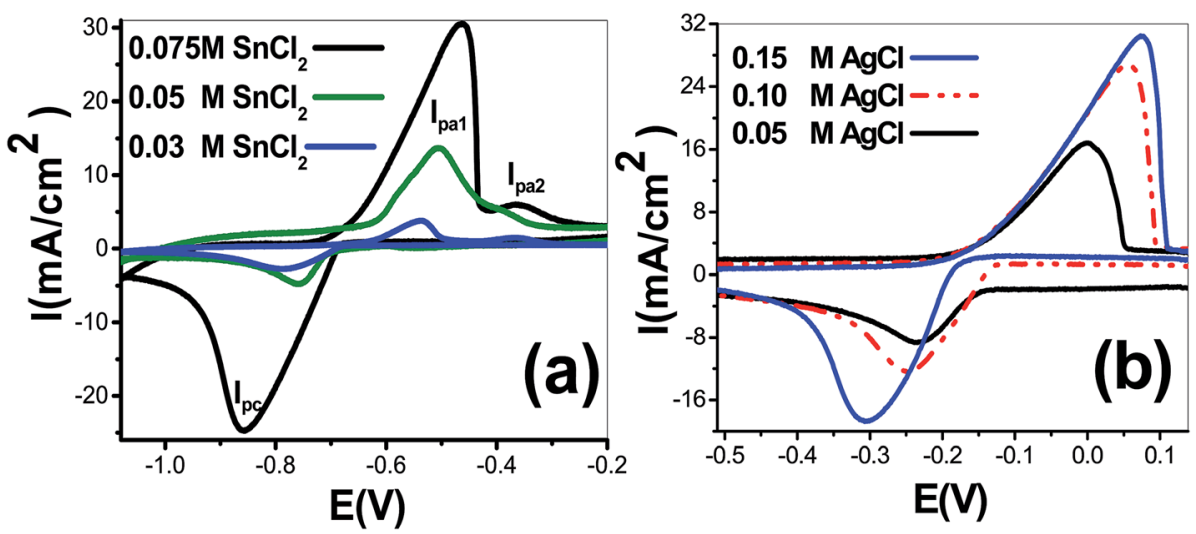

Fig. 1 Cyclic voltammetry curves at scanning rate $50 \mathrm{mV} \mathrm{s}^{-1}$ for a Pt electrode immersed in $1 \mathrm{ChCl}: 2$ EG with different concentration of (a) $\mathrm{SnCl}_{2}$ and (b) AgCl. 

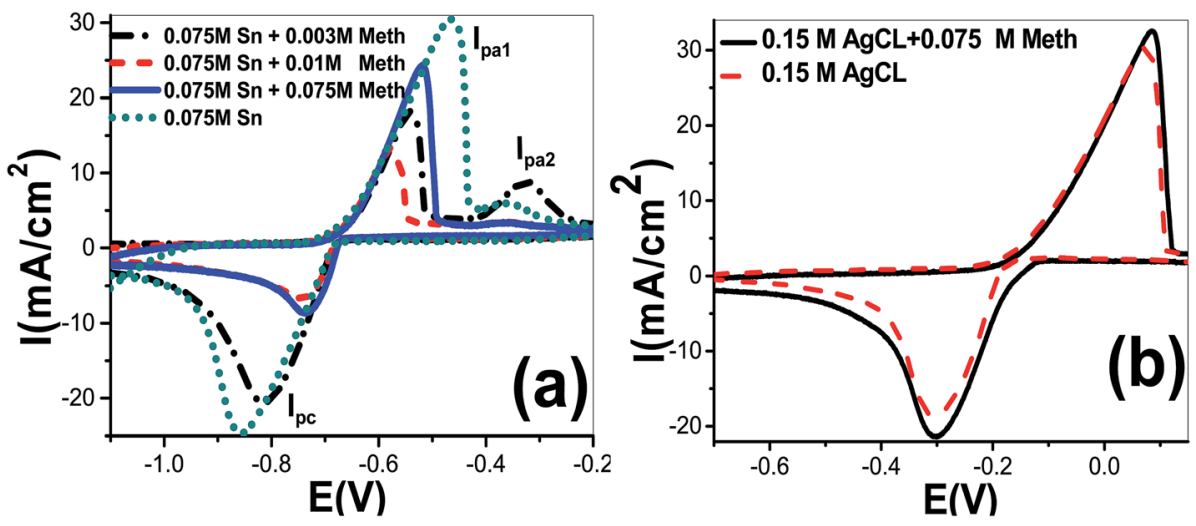

Fig. 2 Cyclic voltammetry curves at $50 \mathrm{mV} \mathrm{s}^{-1}$ scanning rate for a Pt electrode immersed in $1 \mathrm{ChCl}: 2 \mathrm{EG}$ to show the effect of methionine with different concentration of (a) $\mathrm{SnCl}_{2}$ and (b) $\mathrm{AgCl}$.

On the converse scanning, two peaks were detected from the oxidation of $\mathrm{Sn}^{0}$ to $\mathrm{Sn}^{2+}$. Besides, the anodic peaks for tin were shifted from $E_{\mathrm{pa} 1}=-463 \mathrm{mV}$ and $E_{\mathrm{pa} 2}=-361 \mathrm{mV}$ to $-540 \mathrm{mV}$ and $-368 \mathrm{mV}$, respectively, after the incorporation of $0.003 \mathrm{~mol} \mathrm{~L}^{-1}$ methionine. Also, the reduction in peak1 current density was reduced from $I_{\mathrm{pa} 1}=30.56 \mathrm{~mA} \mathrm{~cm}{ }^{-2}$ to $18.27 \mathrm{~mA}$ $\mathrm{cm}^{-2}$. By increasing concentration of methionine to $0.01 \mathrm{~mol} \mathrm{~L}^{-1}$, the anodic peak 1 potential is shifted to $-578 \mathrm{mV}$ with $I_{\mathrm{pa} 1}=13.38 \mathrm{~mA} \mathrm{~cm}{ }^{-2}$. So, the addition of methionine strongly effects on oxidation of $\mathrm{Sn}^{0}$ to $\mathrm{Sn}^{2+}$ ions. This agrees well with previously reported works utilizing other additions. ${ }^{12-14}$

3.1.4. Influence of methionine on the reduction potential of Ag. Fig. 2(b) showed the influence of methionine on the oxidation and reduction potentials of Ag. Without methionine, the reduction of $\mathrm{Ag}^{+}$to $\mathrm{Ag}^{0}$ starts to happen at about $-167 \mathrm{mV}$. The position of the reduction peak is reduced from $-307 \mathrm{mV}$ to $-301 \mathrm{mV}$ and its current density is changed from -18.75 to $-21.42 \mathrm{~mA} \mathrm{~cm}^{-2}$ with the addition of $0.075 \mathrm{~mol} \mathrm{~L}^{-1}$ methionine. On the inverse scanning, Fig. 2(b), only one stripping peak is detected due to the oxidation of $\mathrm{Ag}^{0}$ to $\mathrm{Ag}^{+}$. Additionally, the anodic peak of silver is shifted to more positive potential from 73 to $85 \mathrm{mV}$, which indicates that the incorporation of methionine effects on oxidation of $\mathrm{Ag}^{0}$ to $\mathrm{Ag}^{+}$. Also, the anodic peak current density was increased from $I_{\mathrm{pa}}=30.45 \mathrm{~mA} \mathrm{~cm}{ }^{-2}$ to $32.55 \mathrm{~mA} \mathrm{~cm}^{-2}$ with the addition of $0.075 \mathrm{~mol} \mathrm{~L}^{-1}$ methionine. From Fig. 2(a and b), it is noted that the gap between the reduction peaks of tin and silver is reduced from $550 \mathrm{mV}$ without methionine to $436 \mathrm{mV}$ with the addition of $0.075 \mathrm{~mol} \mathrm{~L}^{-1}$ methionine. Ag/Sn alloys cannot be freely codeposited because the reducing potential of the constituents (Ag, Sn) are far apart. ${ }^{11}$ Two strategies are followed to partly solve this issue; preserving a small concentration of the more noble metal in the solution and introducing additives to reduce the potential gap. ${ }^{11-13}$ Therefore, a small concentration of $\mathrm{Ag}$ will be optimized and used in our study. This approach has been applied through many studies for different structures which includes $\mathrm{Cu} / \mathrm{Ni}$ and $\mathrm{Cu} / \mathrm{Co}$, in which there is a wide potential gap between the depositing potentials of the two metals. ${ }^{15,16}$ The 2nd approach that used to simplify co-deposition is the reduction of the potential gap between the two constituents utilizing additives such as methionine. ${ }^{17}$ Therefore, the inclusion of methionine can facilitate the ( $\mathrm{Sn}, \mathrm{Ag}$ ) co-deposition by reducing the potential gap between the reduction peak of silver and reduction peak of tin. These findings agree well with the results of Low and Walsh for the deposition of $\mathrm{Cu}-\mathrm{Sn}$ alloys utilizing other additives. ${ }^{12}$

3.1.5. Co-deposition of silver and Tin. Fig. 3 displays cyclic voltammograms for a solution holding both $\mathrm{Ag}$ and $\mathrm{Sn}$ ions measured at $50 \mathrm{mV} \mathrm{s}^{-1}$ scan rate and potential range of -2 to $+2 \mathrm{~V}$ to determine the appropriate current and potential for the electro-deposition of $\mathrm{Sn} / \mathrm{Ag}$ alloys. The concentration of $\mathrm{SnCl}_{2}$ was kept at $0.075 \mathrm{~mol} \mathrm{~L}^{-1}$ and $\mathrm{AgCl}$ concentration was varied from 0.005 to $0.1 \mathrm{~mol} \mathrm{~L}^{-1}$. The first observed cathodic peak at $E_{\mathrm{pc} 1}=-752 \mathrm{mV}$ with $I_{\mathrm{pc} 1}=-5.7 \mathrm{~mA} \mathrm{~cm}^{-2}$ can be attributed to $\mathrm{Sn} / \mathrm{Sn}-\mathrm{Ag}$ alloy. As the $\mathrm{AgCl}$ concentration increased to $0.1 \mathrm{~mol} \mathrm{~L}^{-1}$, the width of the cathodic peak 1 increased and the current density also increased to $-8.69 \mathrm{~mA} \mathrm{~cm} \mathrm{~cm}^{-2}$. Another cathodic peak 2 centered at $-232 \mathrm{mV}$ with current density -0.23 $\mathrm{mA} \mathrm{cm}{ }^{-2}$ was observed at $0.05 \mathrm{~mol} \mathrm{~L}^{-1} \mathrm{AgCl}$. This peak is shifted to $-220 \mathrm{mV}$ and the current density increased to -4.77 $\mathrm{mA} \mathrm{cm}{ }^{-2}$. A third cathodic peak for $\mathrm{Sn}-\mathrm{Ag}$ alloy was observed at about $-0.6 \mathrm{~V}$ and its current density is highly increased in the potential window from -0.60 to $-0.67 \mathrm{~V}$ for $\mathrm{AgCl}$ concentration $\geq 0.05 \mathrm{~mol} \mathrm{~L}^{-1}$ as indicated in Fig. 3. The height of the cathodic

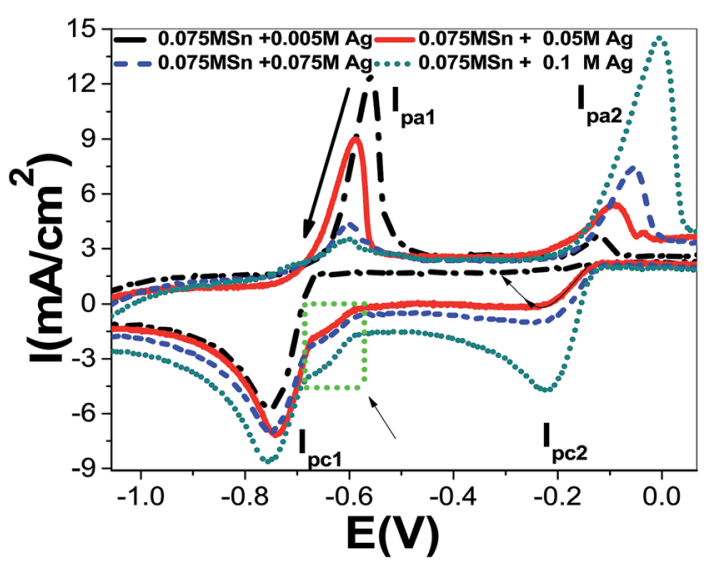

Fig. 3 Voltammograms (scanning rate $50 \mathrm{mV} \mathrm{s}^{-1}$ ) for a Pt electrode (0.50 mm diameter) dipped in $1 \mathrm{ChCl}: 2 \mathrm{EG}$ with different concentration of $\mathrm{AgCl}$ and $0.075 \mathrm{~mol} \mathrm{~L}^{-1} \mathrm{SnCl}_{2}$. 


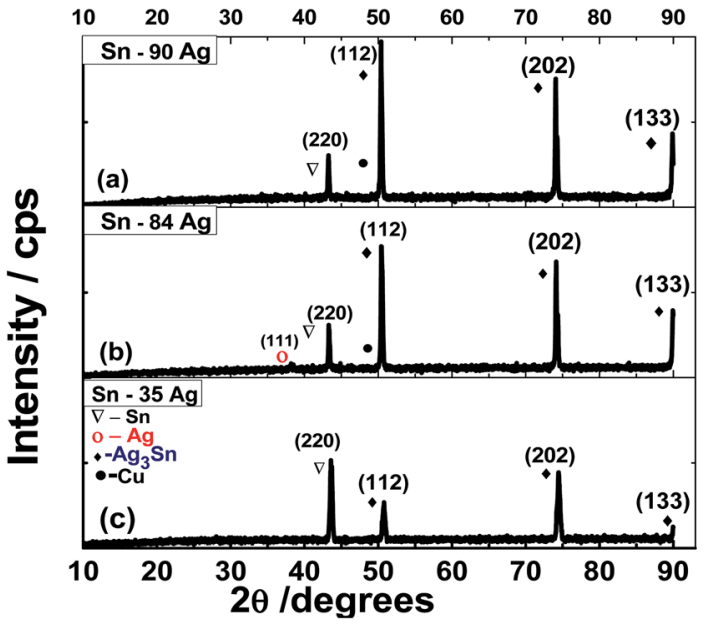

Fig. 4 XRD charts of (a) $\mathrm{Sn}-90 \% \mathrm{Ag}$, (b) $\mathrm{Sn}-84 \% \mathrm{Ag}$ and (c) $\mathrm{Sn}-35 \% \mathrm{Ag}$.

current peak increases with the increase of $\mathrm{AgCl}$ concentration. The reverse scan shows two anodic stripping peaks positioned at $E_{\mathrm{pa} 1}=-559 \mathrm{mV}$ and $E_{\mathrm{pa} 2}=-121 \mathrm{mV}$ with current densities of $I_{\mathrm{pa} 1}=12.36 \mathrm{~mA} \mathrm{~cm}{ }^{-2}$ and $I_{\mathrm{pa} 2}=3.67 \mathrm{~mA} \mathrm{~cm}^{-2}$ for $0.005 \mathrm{~mol} \mathrm{~L}^{-1} \mathrm{AgCl}$. As $\mathrm{AgCl}$ concentration increased to $0.10 \mathrm{~mol} \mathrm{~L}^{-1}$, the anodic peaks are shifted to $-608 \mathrm{mV}$ and $-2 \mathrm{mV}$. The current density of the first anodic peak is decreased to $I_{\mathrm{pa} 1}=3.58 \mathrm{~mA} \mathrm{~cm}{ }^{-2}$ whereas the current density of the second peak is increased to $I_{\mathrm{pa} 2}=14.55 \mathrm{~mA} \mathrm{~cm}^{-2}$. The observed peaks positions are different from peaks stripping potentials of tin, Fig. 1(a), and silver, Fig. 1(b).

\subsection{Structural and morphological properties of $\mathrm{Ag} / \mathrm{Sn}$ deposits}

3.2.1. Structural properties. The structural properties of the $\mathrm{Sn} / \mathrm{Ag}$ alloys were investigated using X-ray diffraction (XRD). Fig. 4 illustrated XRD charts of $\mathrm{Sn} / \mathrm{Ag}$ alloys deposited using $\mathrm{AgCl}$ solutions of different concentrations with ionic liquid of $\mathrm{C}_{5} \mathrm{H}_{14} \mathrm{ClNO}$ and $\left(\mathrm{CH}_{2} \mathrm{OH}\right)_{2}(1: 2)$ as a solvent. This XRD analysis

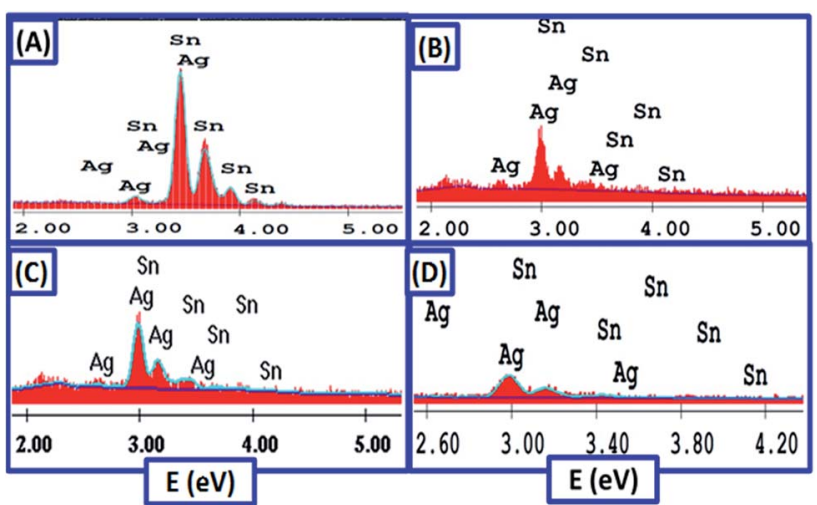

Fig. 5 EDAX spectra of $\mathrm{Sn}-\mathrm{Ag}$ alloys grown from $1 \mathrm{ChCl}: 2 \mathrm{EG}$ containing (A) $0.075 \mathrm{~mol} \mathrm{~L}^{-1} \mathrm{SnCl}_{2}+0.00075 \mathrm{~mol} \mathrm{~L}^{-1} \mathrm{AgCl}$ @ $20 \mathrm{~mA} \mathrm{~cm}^{-2}$ and $1 \mathrm{~V}$ for $25 \mathrm{~min}$; (B) $0.075 \mathrm{~mol} \mathrm{~L}^{-1} \mathrm{SnCl}_{2}+0.005 \mathrm{~mol} \mathrm{~L}^{-1} \mathrm{AgCl}$ (a 17 $\mathrm{mA} \mathrm{cm}{ }^{-2}, 1 \mathrm{~V}$ for $20 \mathrm{~min}$; (C) $0.075 \mathrm{~mol} \mathrm{~L}^{-1} \mathrm{SnCl}_{2}+0.05 \mathrm{~mol} \mathrm{~L}^{-1} \mathrm{AgCl}$ (a $12 \mathrm{~mA} \mathrm{~cm}^{-2}$ and $1 \mathrm{~V}$ for $25 \mathrm{~min}$; and (D) $0.075 \mathrm{~mol} \mathrm{~L}^{-1} \mathrm{SnCl}_{2}+$ $0.075 \mathrm{~mol} \mathrm{~L}^{-1} \mathrm{AgCl}+0.0075 \mathrm{~mol} \mathrm{~L}^{-1}$ methionine a $10 \mathrm{~mA} \mathrm{~cm}^{-2}$ and $0.8 \mathrm{~V}$ for $20 \mathrm{~min}$.

clearly demonstrates the polycrystalline nature of all deposited $\mathrm{Sn} / \mathrm{Ag}$-based films. All films illustrated intensive peaks related to $\mathrm{Ag} / \mathrm{Sn}$ alloy.

The XRD peaks of $\mathrm{Ag} / \mathrm{Sn}$ were observed at $2 \theta=50.7,74.39$, and $89.9^{\circ}$ and indexed to (112), (202), and (133) planes of $\mathrm{Ag}_{3} \mathrm{Sn}$ phase for Orthorhombic packed structure $(a=0.2995 \mathrm{~nm}, c=$ $0.4780 \mathrm{~nm}, c / a=1.5960$; JCPDS card: 00-004-0800), ${ }^{17}$ correspondingly. In all alloys, no other $\mathrm{Ag}_{3} \mathrm{Sn}$ crystalline phases could be detected proving the singularity of the orthorhombic $\mathrm{Ag} / \mathrm{Sn}$ phase and the successful production of this alloy. Also, the peak observed at $43.2^{\circ}$ indicates the presence of tetragonal Sn phase along (200) orientation. ${ }^{\mathbf{1 8 , 1 9}}$ However, the intensity of this peak decreased by increasing Ag concentration. Very tiny (111) $\mathrm{Ag}$ is observed in Fig. 4, especially for $\mathrm{Ag} \% \geq 84 \% .^{18}$ This confirms the successful growth of the $\mathrm{Ag} / \mathrm{Sn}$ alloys. By increasing the $\mathrm{Ag} \%$ from $35 \%$ to $90 \%$, the (112) peak becomes

Table 1 The structural parameters of $\mathrm{Sn}-\mathrm{Ag}$ alloy samples prepared on $\mathrm{Cu}$ substrate grown from $1 \mathrm{ChCl}: 2 \mathrm{EG}$

\begin{tabular}{|c|c|c|c|c|c|}
\hline Compound name & & $\operatorname{Tin}(\mathrm{Sn})$ & Silver tin $\left(\mathrm{Ag}_{3} \mathrm{Sn}\right)$ & $\begin{array}{l}\text { Silver tin } \\
\left(\mathrm{Ag}_{3} \mathrm{Sn}\right)\end{array}$ & $\begin{array}{l}\text { Silver tin } \\
\left(\mathrm{Ag}_{3} \mathrm{Sn}\right)\end{array}$ \\
\hline $2 \theta(\mathrm{deg})$ & & 43.20 & $50.70^{\circ}$ & $74.39^{\circ}$ & $89.9^{\circ}$ \\
\hline Planes & & $(220)$ & $(112)$ & $(202)$ & (113) \\
\hline Crystal system & & Tetragonal & Orthorhombic & & \\
\hline \multirow[t]{3}{*}{ FWHM (degree) } & (a) & 0.0984 & 0.1378 & 0.1440 & 0.20 \\
\hline & (b) & 0.1440 & 0.1440 & 0.1200 & 0.18 \\
\hline & (c) & 0.1440 & 0.32 & 0.1440 & 0.20 \\
\hline \multirow[t]{3}{*}{$I / I_{\mathrm{o}} \%$} & (a) & 25.16 & 100 & 73.71 & 45.89 \\
\hline & (b) & 32.74 & 100 & 85.97 & 51.14 \\
\hline & (c) & 100 & 52.25 & 98.96 & 29.54 \\
\hline \multirow[t]{3}{*}{$D(\mathrm{~nm})$} & (a) & 86.83 & 63.70 & 69.11 & 56.18 \\
\hline & (b) & 59.38 & 61.01 & 83.09 & 62.42 \\
\hline & (c) & 59.42 & 27.48 & 69.26 & 56.18 \\
\hline \multirow[t]{3}{*}{ TC } & (a) & - & 1.37 & 1.01 & 0.63 \\
\hline & (b) & - & 1.27 & 1.09 & 0.65 \\
\hline & (c) & - & 0.87 & 1.64 & 0.49 \\
\hline \multirow[t]{3}{*}{ Dislocation density (dis per $\mathrm{nm}^{2}$ ) } & (a) & 132.64 & 246.45 & 209.37 & 316.84 \\
\hline & (b) & 283.61 & 268.66 & 144.84 & 256.66 \\
\hline & (c) & 283.23 & 1324.24 & 208.47 & 316.84 \\
\hline
\end{tabular}


Table 2 Chemical compositions of nanocrystalline Sn-Ag alloys obtained from EDX analysis

\begin{tabular}{llll}
\hline Sample & Sn\% & $\mathrm{Ag} \%$ & Applied potential \\
\hline A & 65 & 35 & $1 \mathrm{~V}$ \\
B & 35 & 65 & $1 \mathrm{~V}$ \\
C & 3 & 97 & $1 \mathrm{~V}$ \\
D & 16 & 84 & $0.8 \mathrm{~V}$
\end{tabular}

more intense than (202) peak. This reveals the change of the preferred growth orientation from (202) at $35 \% \mathrm{Ag}$ to (112) at $90 \% \mathrm{Ag}$. This may be credited to the variation of equilibrium surface concentration with $\mathrm{Ag} \%$ toward the minimizing of the alloy surface energy or setting the segregation energy near to zero. ${ }^{20} \mathrm{Also}$, no shifts are detected for XRD peaks. This indicates that most of $\mathrm{Ag}$ ions are incorporated into the alloys. ${ }^{17,25}$

The average crystallite size of the alloy is calculated using values of full width at half maximum $(W)$ for the main three $\mathrm{Ag} / \mathrm{Sn}$ peaks through Scherrer's equation; $D_{\mathrm{s}}=0.94 \lambda / W \cos \theta$; in which $\theta$ and $\lambda$ are the Bragg's angle and X-ray wavelength. ${ }^{26,27}$ Also, the texture coefficients (TCs) and dislocation densities are calculated..$^{26,28}$ The calculated structural parameters are presented in Table 1. The average $D_{\mathrm{s}}$ values are $63.94 \mathrm{~nm}, 69.32,55.04 \mathrm{~nm}$ for alloys with $90 \% \mathrm{Ag}, 84 \% \mathrm{Ag}$ and $35 \% \mathrm{Ag}$, respectively. Whereas the (112) crystallite sizes are $63.70,61.01$, and $27.48 \mathrm{~nm}$ for the same alloys. Generally, the reduction in the crystallite size could be accredited to the creation of new nucleating centers caused by the reduction in the nucleation energy barrier. ${ }^{26}$ The reduction of TC values from 1.37 to 1.27 and 0.87 proving the preferred growth of $\mathrm{Ag} / \mathrm{Sn}$ along (112) as the $\mathrm{Ag} \%$ increased and along (202) as the
Sn\% increased in the alloy. Also, the density of crystal imperfections, especially dislocation density is decreased by increasing $\mathrm{Ag} \%$ and increased by increasing $\mathrm{Sn} \%$.

3.2.2. Chemical composition of $\mathrm{Ag} / \mathrm{Sn}$ alloys using EDX spectra. Energy dispersive X-ray (EDX) spectra are shown in Fig. 5 for $\mathrm{Sn}-\mathrm{Ag}$ alloys grown from $1 \mathrm{ChCl}: 2 \mathrm{EG}$ containing $0.075 \mathrm{~mol} \mathrm{~L}^{-1} \mathrm{SnCl}_{2}$ and (a) $0.00075 \mathrm{~mol} \mathrm{~L}^{-1} \mathrm{AgCl}$ (a) $20 \mathrm{~mA}$ $\mathrm{cm}^{-2}$ for $25 \mathrm{~min}$; (b) $0.005 \mathrm{~mol} \mathrm{~L}^{-1} \mathrm{AgCl}$ @ $17 \mathrm{~mA} \mathrm{~cm}{ }^{-2}$ for $20 \mathrm{~min}$; (c) $0.05 \mathrm{~mol} \mathrm{~L}^{-1} \mathrm{AgCl}$ @ $12 \mathrm{~mA} \mathrm{~cm}^{-2}$ for $25 \mathrm{~min}$; and (d) $0.075 \mathrm{~mol} \mathrm{~L}^{-1} \mathrm{AgCl}+0.0075 \mathrm{~mol} \mathrm{~L}^{-1}$ methionine @ $10 \mathrm{~mA} \mathrm{~cm}{ }^{-2}$ for $20 \mathrm{~min}$. The chemical compositions of the examined samples are shown in Table 2. All the spectra show only Ag and Sn signals without any impurity traces from the used chemicals, which indicates the high purity of the deposited $\mathrm{Sn} / \mathrm{Ag}$ alloys.

3.2.3. Morphological properties of Ag/Sn alloys using SEM. The surface morphology of the deposited alloys is studied using a scanning electron microscope (SEM). SEM images of four different $\mathrm{Sn} / \mathrm{Ag}$ alloys formed on the surface of $\mathrm{Cu}$ foil from 1 $\mathrm{ChCl}: 2 \mathrm{EG}$ are displayed in Fig. 6(A-D). From SEM images, it is evident that the morphology of the alloy can be reformed by governing its chemical composition. It is important to note from Fig. 6(A) that rougher and larger precipitates can be observed in the microstructure that deposited from the Sn-rich liquid than that formed from the Ag-rich liquid in Fig. 6(B and C) or formed from the Ag-rich deposit with methionine in Fig. 6(D). The change of alloy morphology and roughness with the change in composition may be ascribed to the change in the rate of deposition, Fig. 3; the electrochemistry of the components in solution, specially the strong hydrogen bond donors $(\mathrm{ChCl}$ : ethylene glycol) and metals concentration $(\mathrm{Ag}, \mathrm{Sn})$. At

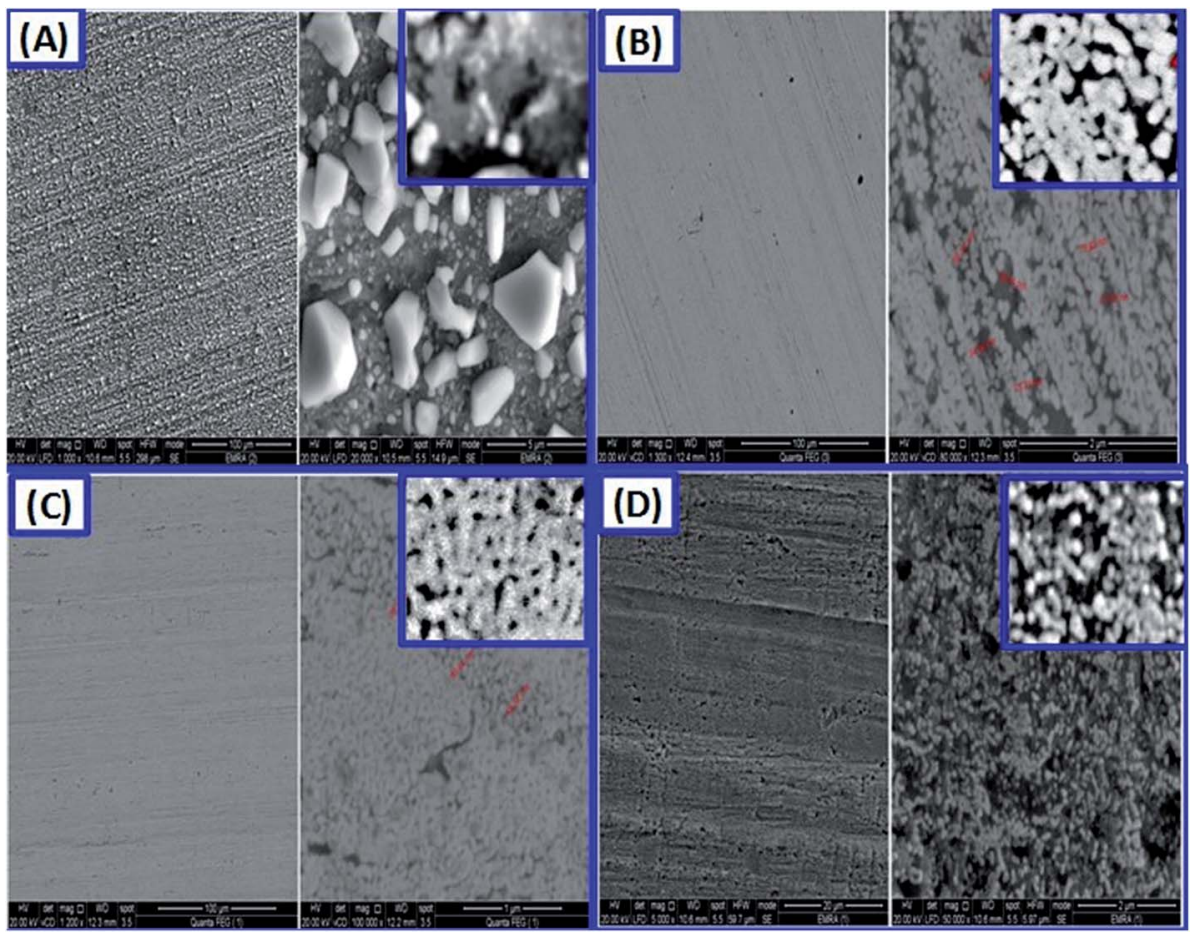

Fig. 6 SEM images of Sn-Ag alloys grown from $1 \mathrm{ChCl}: 2 \mathrm{EG}$ containing (A) $0.075 \mathrm{~mol} \mathrm{~L}^{-1} \mathrm{SnCl}_{2}+0.00075 \mathrm{~mol} \mathrm{~L}^{-1} \mathrm{AgCl}^{\text {a } 20 ~ m A ~ c m} \mathrm{ma}^{-2}$ and for $25 \mathrm{~min}$; (B) $0.075 \mathrm{~mol} \mathrm{~L}^{-1} \mathrm{SnCl}_{2}+0.005 \mathrm{~mol} \mathrm{~L}^{-1} \mathrm{AgCl}$ @ $17 \mathrm{~mA} \mathrm{~cm}^{-2}, 1 \mathrm{~V}$ for $20 \mathrm{~min}$; (C) $0.075 \mathrm{~mol} \mathrm{~L}^{-1} \mathrm{SnCl}_{2}+0.05 \mathrm{~mol} \mathrm{~L}-1 \mathrm{AgCl}^{\circ} 12 \mathrm{~mA}$ $\mathrm{cm}^{-2}$ and $1 \mathrm{~V}$ for $25 \mathrm{~min}$; and (D) $0.075 \mathrm{~mol} \mathrm{~L}^{-1} \mathrm{SnCl}_{2}+0.075 \mathrm{~mol} \mathrm{~L}^{-1} \mathrm{AgCl}+0.0075 \mathrm{~mol} \mathrm{~L}^{-1}$ methionine $@ 10 \mathrm{~mA} \mathrm{~cm}^{-2}$ and $0.8 \mathrm{~V}$ for $20 \mathrm{~min}_{\text {. }}$ 

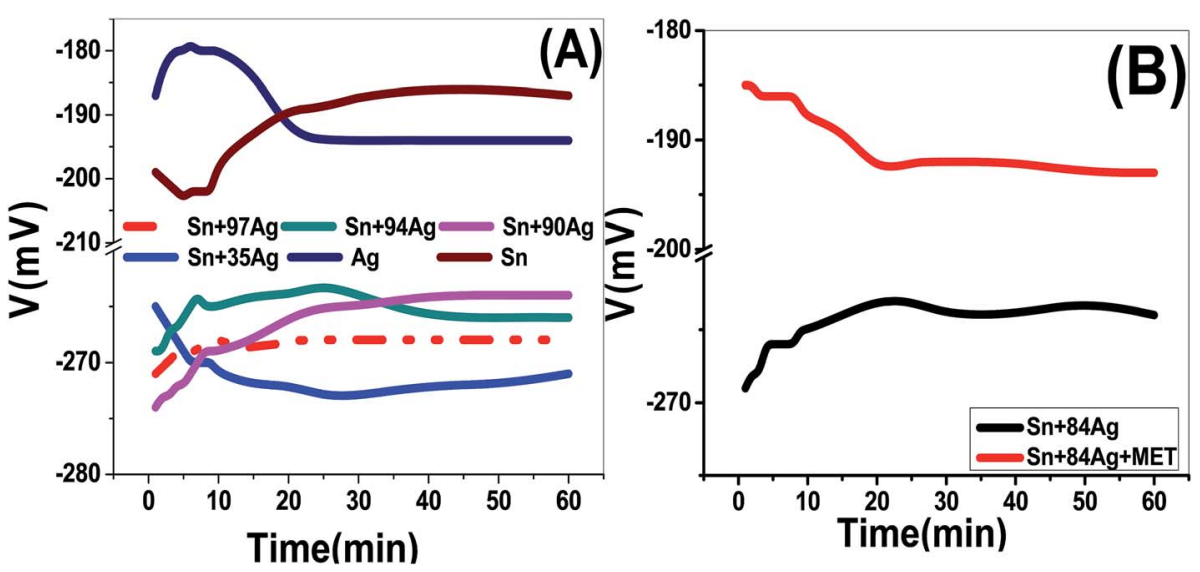

Fig. 7 Variation of the open-circuit potential with time for electrodeposited (A) Nano Ag, Sn, and Sn-Ag alloys, and (B) methionine/Sn-Ag immersed in stagnant aerated $\mathrm{NaOH}$ solution $\left(0.5 \mathrm{~mol} \mathrm{~L}^{-1}\right)$ at $25^{\circ} \mathrm{C}$.

a high current density in the rich Sn solution, the deposited alloy is irregular with low crystallinity and small crystallite size. By increasing Ag content in Sn rich solution, the surface of the deposited alloy becomes porous at higher current density with high crystallites sizes and smooth surface due to the simultaneous hydrogen evolution and self-agglomeration of the crystallites. Similar results were reported by Sharma et al. about the effect of current density in the morphology of Sn deposits. ${ }^{29}$

Spherical and granular structures are observed in Fig. 6(A), whereas the quantitative analysis for the alloy is $65 \% \mathrm{Sn}$ and $35 \% \mathrm{Ag}$ from Fig. 5(A). The SEM images of the alloy in Fig. 6(BD) show that the method has been successful with silver-rich alloys. With increasing the Ag\%, smooth surfaces are obtained as shown in Fig. 6(B and C) because of the increase of Ag concentration in the $1 \mathrm{ChCl}: 2 \mathrm{EG}$ solution and the noticeable decrease in the observed current density. However, the alloy in Fig. 6(C) with 97\% Ag shows more homogeneous and smooth surface than that of the alloy with $65 \% \mathrm{Ag} \%$ (Fig. 6(B)). As presented in the inset of Fig. $6(\mathrm{C})$, the nanoparticles of the alloy are agglomerated and to some degree form a nanoporous film with a homogenous surface. This nanoporous nature may be the reason for the existence of very limited XRD $\mathrm{Cu}$ signal in Fig. 4(b). In Fig. 6(D), the use of the additive substances like the methionine addition to $1 \mathrm{ChCl}: 2 \mathrm{EG}$ advances the surface morphology of the deposited film and prevents the agglomeration. Such combination produces fine spherical nanogranules of Ag-Sn alloy. As observed, the surface morphologies are influenced by the electro-deposition current density and the addition of methionine decreases the current density from 20 $\mathrm{mA} \mathrm{cm}{ }^{-2}$ at $1 \mathrm{~V}$ to $10 \mathrm{~mA} \mathrm{~cm}{ }^{-2}$ at $0.8 \mathrm{~V}$. Also, the addition of methionine reduces the deposition time from 25 to $20 \mathrm{~min}$ because of its catalytic effect.

\subsection{Open circuit potentials measurements}

The open circuit potentials (OCPs) of Sn, Ag, Sn-35Ag, Sn-90Ag, Sn-94Ag, and Sn-97Ag alloys were drawn over $60 \mathrm{~min}$ in $0.5 \mathrm{~mol} \mathrm{~L}^{-1} \mathrm{NaOH}$ solution and shown in Fig. 7(A). An increase in the OCP was recorded in the first few minutes for $\mathrm{Sn}, \mathrm{Sn}-$ 90Ag, Sn-94Ag, and Sn-97Ag alloys. Then, the steady states were achieved for $25 \mathrm{~min}$. For these electrodes, OCPs become more positive with time referring to a natural affinity of Sn, Sn-90Ag, Sn-94Ag, and Sn-97Ag for passivation in ILs. The Ag and Sn$35 \mathrm{Ag}$ electrodes show reverse behavior with remarkably negative steady-state OCPs. The measurements are suggesting that the HER on Sn-35Ag and Sn-97Ag alloys will occur at lower potentials than other alloys.

The effect of methionine addition on the OCP of Sn-84Ag electrode was recorded over $1 \mathrm{~h}$ in $0.5 \mathrm{~mol} \mathrm{~L}^{-1} \mathrm{NaOH}$ solution and shown in Fig. 7(B). Within the first $22 \mathrm{~min}$, OCP is increased for $\mathrm{Sn}-84 \mathrm{Ag}$ and decreased for $\mathrm{Sn}-84 \mathrm{Ag}$ with methionine. Then, the OCP of both electrodes reached the steadystate value. Also, the OCP shifted towards more positive values for $\mathrm{Sn}-84 \mathrm{Ag}$ and towards more negative values for $\mathrm{Sn}$ $84 \mathrm{Ag}$ with methionine. The OCP at the steady state is reduced by $72 \pm 2 \mathrm{mV}$ after the addition of methionine to Sn-84Ag alloy, suggesting the catalytic contribution of methionine.

\subsection{Electrocatalytic activities}

3.4.1. Polarization measurements. The electrocatalytic activities of the deposited $\mathrm{Sn}-\mathrm{Ag}$ films (cathodes) for HERs were

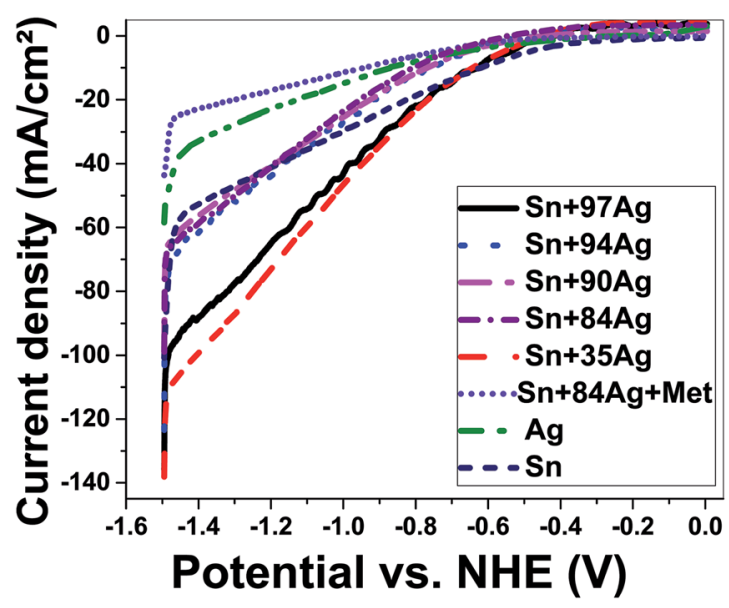

Fig. 8 Cathodic polarization for electrodeposited nano Ag, Sn, Sn-Ag alloys, and methionine/Sn-Ag dipped in $\mathrm{NaOH}$ solution $\left(0.5 \mathrm{~mol} \mathrm{~L}^{-1}\right)$ at $25^{\circ} \mathrm{C}$. NHE (normal/standard hydrogen electrode). 
Table 3 Values of $\mathrm{H}_{2}$ evolution rate of deposited $\mathrm{Sn}, \mathrm{Ag}, \mathrm{Sn}-\mathrm{Ag}$ alloys, and methionine/Sn-Ag alloy dipped in $0.5 \mathrm{~mol} \mathrm{~L}-1 \mathrm{NaOH}$ solution at $25^{\circ} \mathrm{C}$

\begin{tabular}{|c|c|c|c|c|c|c|}
\hline Materials & $i_{-2.5 \mathrm{v}}\left(\mathrm{mA} \mathrm{cm}^{-2}\right)$ & $i_{-2.2 \mathrm{v}}\left(\mathrm{mA} \mathrm{cm}^{-2}\right)$ & $i_{-1.9 \mathrm{v}}\left(\mathrm{mA} \mathrm{cm}^{-2}\right)$ & $i_{-1.6 \mathrm{v}}\left(\mathrm{mA} \mathrm{cm}^{-2}\right)$ & $i_{-1.3 \mathrm{v}}\left(\mathrm{mA} \mathrm{cm}^{-2}\right)$ & $i_{-1.0 \mathrm{v}}\left(\mathrm{mA} \mathrm{cm}^{-2}\right)$ \\
\hline Sn-84Ag & 98.86 & 40.47 & 15.65 & 1.29 & 2.97 & 3.46 \\
\hline Sn-90Ag & 100.79 & 40.93 & 23.93 & 8.74 & 1.61 & 0.51 \\
\hline Sn-97Ag & 135.87 & 64.26 & 31.23 & 6.99 & 2.57 & 3.79 \\
\hline $\mathrm{Sn}-35 \mathrm{Ag}$ & 138.13 & 72.16 & 33.67 & 6.90 & 3.78 & 4.51 \\
\hline $\mathrm{Sn}-84 \mathrm{Ag}+\mathrm{Met}$ & 43.62 & 16.94 & 8.58 & 2.14 & 0.46 & 0.13 \\
\hline
\end{tabular}

studied thru electrochemical polarization (ECP) measurements and EC impedance spectroscopies (EISs) in $0.5 \mathrm{~mol} \mathrm{~L}^{-1} \mathrm{NaOH}$ solution. The HERs in alkaline liquids occurs thru three reactions: ${ }^{30,31}$ (i) Volmer reaction (reduction of $\mathrm{H}_{2} \mathrm{O}$ molecule and adsorption of hydrogen on the electrode surface; $\mathrm{H}_{2} \mathrm{O}+\mathrm{M}+\mathrm{e}^{-}$ $\leftrightarrow \mathrm{MH}_{(\mathrm{ad})}+\mathrm{HO}^{-}$), (ii) Heyrovsky reaction (desorption of the surface $\mathrm{H}$-atom, formation of $\mathrm{H}_{2}$ and concurrent reduction of one $\mathrm{H}_{2} \mathrm{O}$ molecule; $\mathrm{MH}_{(\mathrm{ad})}+\mathrm{H}_{2} \mathrm{O}+\mathrm{e}^{-} \leftrightarrow \mathrm{M}+\mathrm{HO}^{-}+\mathrm{H}_{2}$ ), and (iii) Tafel reaction (combination of two adjacent adsorbed $\mathrm{H}$-atoms and formation of $\mathrm{H}_{2}$ molecule; $2 \mathrm{MH}_{(\mathrm{ad})} \leftrightarrow 2 \mathrm{M}+\mathrm{H}_{2}$ ). The interaction strengths of $\mathrm{M}-\mathrm{H}_{2} \mathrm{O}$ and $\mathrm{M}-\mathrm{H}_{\text {ads }}$ plays the main character in the mechanisms and kinetics of HERs. Both Volmer-Heyrovsky reaction and Volmer-Tafel reaction started with $\mathrm{M}-\mathrm{H}_{\text {ads }}$ formation and ended with $\mathrm{M}-\mathrm{H}_{\text {ads }}$ bond dissociation. The strong $\mathrm{M}-\mathrm{H}_{2} \mathrm{O}$ interaction is favorable for $\mathrm{H}_{2} \mathrm{O}$ splitting but the so strong interaction will obstruct $\mathrm{H}_{2}$ desorption. So, the model cathode must balance the formation and dissociation reaction of $\mathrm{M}-\mathrm{H}_{\mathrm{ads}}$ to obtain high rates of HERs. ${ }^{32,33}$ The electrocatalytic activities for HERs were evaluated thru ECP measurements and displayed in Fig. 8 using electrodeposited $\mathrm{Sn}-\mathrm{Ag}$ cathodes with varied $\mathrm{Ag} \%$ in $0.5 \mathrm{~mol} \mathrm{~L}^{-1}$ $\mathrm{NaOH}$ solution. The experimentally measured potential versus $\mathrm{Ag} / \mathrm{AgCl}, E_{\mathrm{Ag} / \mathrm{AgCl}}$, was calibrated with respect to the NHE (normal/standard hydrogen electrode), $E_{\mathrm{NHE}}$, according to the Nernst equation; ${ }^{34} E_{\mathrm{NHE}}=E_{\mathrm{Ag} / \mathrm{AgCl}}+E_{\mathrm{Ag} / \mathrm{AgCl}}^{0}+0.059 \mathrm{pH}$ (at 25 ${ }^{\circ} \mathrm{C}$ ). Where $E_{\mathrm{Ag} / \mathrm{AgCl}}^{0}=0.1976 \mathrm{~V}$ at $25^{\circ} \mathrm{C}$, and the HER experimental recorded in $0.5 \mathrm{M} \mathrm{NaOH}$ solution $(\mathrm{pH}=13.69)$. From Fig. 8, the activity of Sn-35Ag, Sn-97Ag alloy is notably higher than ed. Sn, ed. Ag. ${ }^{35}$ The hydrogen reduction overpotential and current density are considered the main characters to control the electrodes activities and rates of HERs. Hence, the rate of hydrogen evolution is directly proportional to the cathodic current density. Table 3 displayed the estimated current densities for the different electrodes at different potential values. Fig. 8 and Table 3 clearly confirm the increase of current density and hence hydrogen production rate by rising $\mathrm{Ag} \%$ from $84 \%$ up to $97 \%$. Also, the hydrogen production rate is increased by raising the applied potential. A clear assessment of the catalytic activities of the varies cathodes at a particular potential is obtained from Fig. 8, whereas the overpotentials are decreased and hydrogen production rates are increased, i.e., the cathodic current densities are increased, ${ }^{8,36}$ except in the case of methionine additive, a noticeable decrease is observed in the hydrogen overpotential and production rate. The best alloys that give a high rate of hydrogen production are $\mathrm{Sn}-35 \mathrm{Ag}$ and
Sn-97Ag. This may be accredited to the nanoporous structure which possesses higher surface area. The higher evaluation activities of Sn-Ag may result from the synergistic combination of Sn and Ag. The main reason for high hydrogen evolution using Sn-97Ag is due to the increase of silver content in the alloy. But in case of Sn-35Ag, the HER may be related to the structural and morphological properties of this alloy like the existence of mixing tetragonal Sn and orthorhombic (202) $\mathrm{Ag}_{3} \mathrm{Sn}$, and the existence of spherical and granular structures at the surface to produce rough high surface area to volume ratio. ${ }^{37}$ The relatively low electrocatalytic activity of Sn-84Ag, Sn-90Ag alloys could be attributed to the smooth surface which leads to the small surface area to volume ratio. ${ }^{7}$ Table 4 displayed the steady state potential and the starting potential of hydrogen evaluation for all electrodes under identical conditions. The steady state potentials of $\mathrm{Sn}-\mathrm{Ag}$ cathodes are more negative than that recorded for Sn or Ag. Then, the nanostructured nature of the electrodes enhances the catalytic activities of the electrodes for efficient HERs. The increase of the $\mathrm{Ag}$ content up to $84 \%$ to $97 \%$ result in a reduction of the cathodic overpotential by about $185 \mathrm{mV}(-1580 \mathrm{mV}$ for Sn-84Ag and $-1395 \mathrm{mV}$ for Sn-97Ag). Both of the Sn-35Ag and Sn-97Ag give high current densities and low overpotentials. Also, both of the $\mathrm{Sn}-35 \mathrm{Ag}$ and $\mathrm{Sn}-97 \mathrm{Ag}$ exhibited a reasonably more positive overpotential relative to the other $\mathrm{Sn}-\mathrm{Ag}$ alloys, indicating the enhanced electrocatalytic activity of both $\mathrm{Sn}-35 \mathrm{Ag}$ and $\mathrm{Sn}-97 \mathrm{Ag}$ alloys towards the HER. ${ }^{8}$

The effect of methionine addition during the deposition of Sn-84Ag alloy on the amount of hydrogen evolution (current density) can be figured out from curves of methionine/Sn-84Ag and $\mathrm{Sn}-84 \mathrm{Ag}$ electrodes in Fig. 8. As the potential changed from $-1 \mathrm{~V}$ to $-2.5 \mathrm{~V}$, the current density is changed from +3.46 to

Table 4 The values of steady-state potential, $\mathrm{H}_{2}$ evolution potential, and cathodic $\mathrm{H}_{2}$ overpotential in $0.5 \mathrm{~mol} \mathrm{~L}^{-1} \mathrm{NaOH}$ at $25^{\circ} \mathrm{C}$

\begin{tabular}{llll}
\hline Materials & $E_{\text {ss }} / \mathrm{mV}$ & $E_{\text {Hydrogen evolution }} / \mathrm{mV}$ & $\begin{array}{l}\text { Cathodic hydrogen } \\
\text { overpotential } / \mathrm{mV}\end{array}$ \\
\hline Sn-84Ag & -264 & -1580 & -1316 \\
Sn-90Ag & -264 & -1548 & -1284 \\
Sn-94Ag & -266 & -1560 & -1294 \\
Sn-97Ag & -268 & -1395 & -1127 \\
Sn-35Ag & -271 & -1420 & -1149 \\
Sn-84Ag + Met & -187 & -1285 & -1098 \\
Ag-deposited & -194 & -1490 & -1296 \\
Sn-deposited & -193 & -1362 & -1169
\end{tabular}



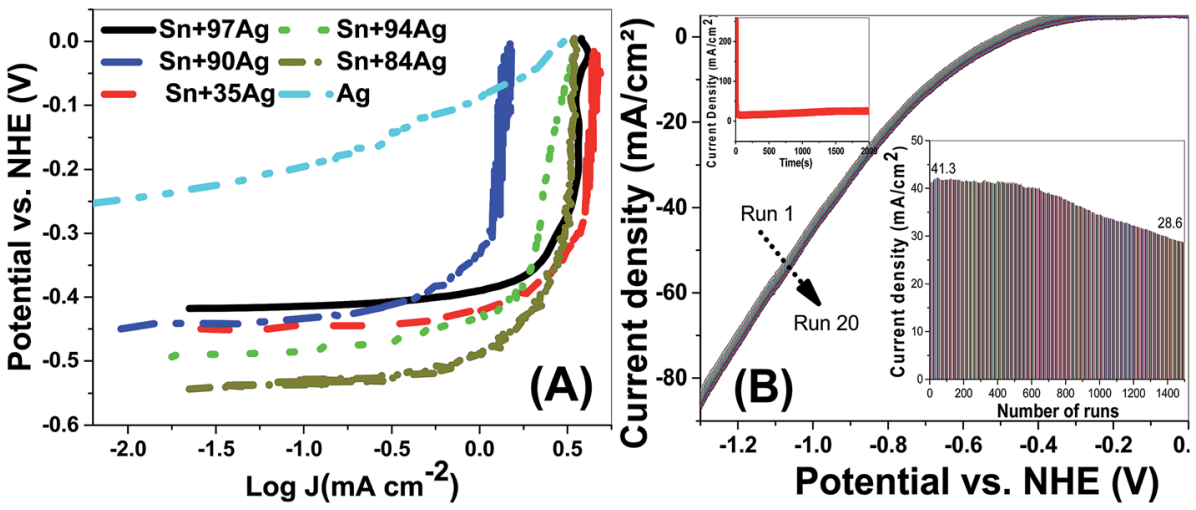

Fig. 9 (A) Tafel slopes for HER using different electrodes in $0.5 \mathrm{M} \mathrm{NaOH}$ at $25^{\circ} \mathrm{C}$ and (B) stability study as a function of the number of runs and evolution time.

$-98.86 \mathrm{~mA} \mathrm{~cm}^{-2}$ for $\mathrm{Sn}-84 \mathrm{Ag}$ electrode and from +0.13 to $-43.62 \mathrm{~mA} \mathrm{~cm} \mathrm{~cm}^{-2}$ for methionine/Sn-84Ag electrode. This means that $\mathrm{Sn}-84 \mathrm{Ag}$ electrode showed higher catalytic activity than methionine/Sn-84Ag during the HER measurements. Also from Table 4, the addition of methionine to $\mathrm{Sn}-84 \mathrm{Ag}$ shifts the cathodic hydrogen overpotential and hydrogen evolution potential to the positive direction, which can be confirmed by the obtained results in Fig. 2. Although the role of the methionine in reducing the reduction potential of $\mathrm{Sn}^{2+}$ to $\mathrm{Sn}$ during deposition of $\mathrm{Sn}-\mathrm{Ag}$ alloy, however its use is suppressing the catalytic activity of $\mathrm{Sn}-84 \mathrm{Ag}$ electrode.

To understand the HER mechanism Tafel slopes were derived from the polarization curves, Fig. 8. The Tafel slopes of the HERs were estimated by considering the linear portions of the $E_{\mathrm{NHE}}-\log (J)$ plots as shown in Fig. 9(A). The obtained Tafel slopes $\left(\beta_{1}\right.$ and $\left.\beta_{2}\right)$ at low and high overpotential domains of $\mathrm{Ag}$ and $\mathrm{Sn}-\mathrm{Ag}$ electrodes are presented in Table 5 . These values can be used as a guide to identifying the HER mechanisms, a Tafel slope of $\sim 30 \mathrm{mV}$ per decade suggests that the mechanism proceeds through Volmer-Tafel mechanism and the recombination step is rate limiting. A Tafel slope of $\sim 40 \mathrm{mV}$ per decade suggests hydrogen production via the Volmer-Heyrovsky mechanism and the electrochemical desorption step is ratelimiting. Finally, a Tafel slope of $\sim 120 \mathrm{mV}$ per decade may arise from various reaction pathways depending on the surface coverage of adsorbed hydrogen. Because Tafel slope simply tells us how much the overpotential should be increased to increase the reaction rate by a factor ten, then the obtained values for Sn$35 \mathrm{Ag}$ and Sn-97Ag can be used to confirm their high performance in HER.

Table 5 Tafel slopes $\left(\beta_{1}\right.$ and $\left.\beta_{2}\right)$ at low and high overpotential domains of $\mathrm{Ag}$, and $\mathrm{Sn}-\mathrm{Ag}$ electrodes prepared with different $\mathrm{Ag} \%$

\begin{tabular}{lll}
\hline Alloys & $\beta_{1}\left(\mathrm{mV} \mathrm{dec}^{-1}\right)$ & $\beta_{2}\left(\mathrm{mV} \mathrm{dec}^{-1}\right)$ \\
\hline Sn-35Ag & 15.1 & 109.0 \\
Sn-84Ag & 27.7 & 130.1 \\
Sn-90Ag & 28.5 & 204.8 \\
Sn-94Ag & 24.1 & 191.9 \\
Sn-97Ag & 12.2 & 108.1 \\
Ag-deposited & 29.3 & 117.3
\end{tabular}

The electrochemically active surface area (ECSA) of the electrodes was calculated using ECSA $=Q /(m C)$ where $Q$ is hydrogen adsorption charge in the negative-going scan after correction for double-layer charging, $m$ is the catalyst mass loading, and $C$ is the charge of full monolayer coverage of $\mathrm{H}$ atoms onto electrode. ${ }^{38} Q$ is obtained by integrating the currentpotential curve and then by dividing the calculated value by the scan rate of the measurement. The ECSA values of Sn-Ag alloys relative to pure $\mathrm{Ag}\left(16.69 \mathrm{~m}^{2} \mathrm{~g}^{-1}\right)$ were estimated to be $\sim 2.62$, $1.69,1.61,1.51$, and 2.88. For $\mathrm{Sn}-\mathrm{Ag}$ electrodes with different $\mathrm{Ag}$ ratios of $97 \%, 94 \%, 90 \%, 84 \%$ and $35 \%$. The high ECSA values for $\mathrm{Sn}-35 \mathrm{Ag}$ and $\mathrm{Sn}-97 \mathrm{Ag}$ electrodes also clarify their high performance in HERs.

The stability of Sn-35Ag electrode was studied as a function of the number of runs and as a function of the exposure time, Fig. 9(B). This electrode showed very high stability over the applied potential range during 200 runs. Only degradation less than $1 \%$ is observed after 500 runs. The electrocatalytic activity degraded after 500 cycles, as shown in the inset, the electrical connectivity was maintained even after 2000 runs. For $N>500$ runs, the degradation rate was $0.02 \%$ per run. Also, the inset red curve of Fig. 9(B) showed the current density versus HER time up to $2000 \mathrm{~s}$, which also confirms the high stability of Sn-35Ag electrode during HER. ${ }^{39}$

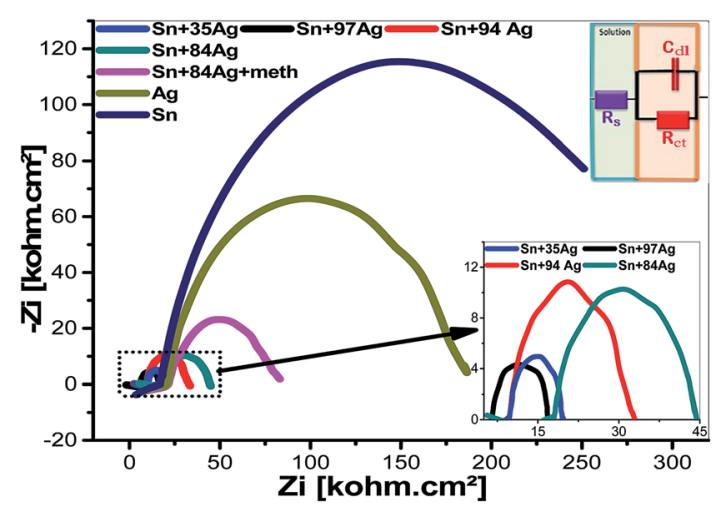

Fig. 10 Nyquist plots for the prepared alloys at the hydrogen evolution potential in $0.5 \mathrm{~mol} \mathrm{~L}^{-1} \mathrm{NaOH}$ stagnant naturally aerated aqueous liquid at $25^{\circ} \mathrm{C}$. 


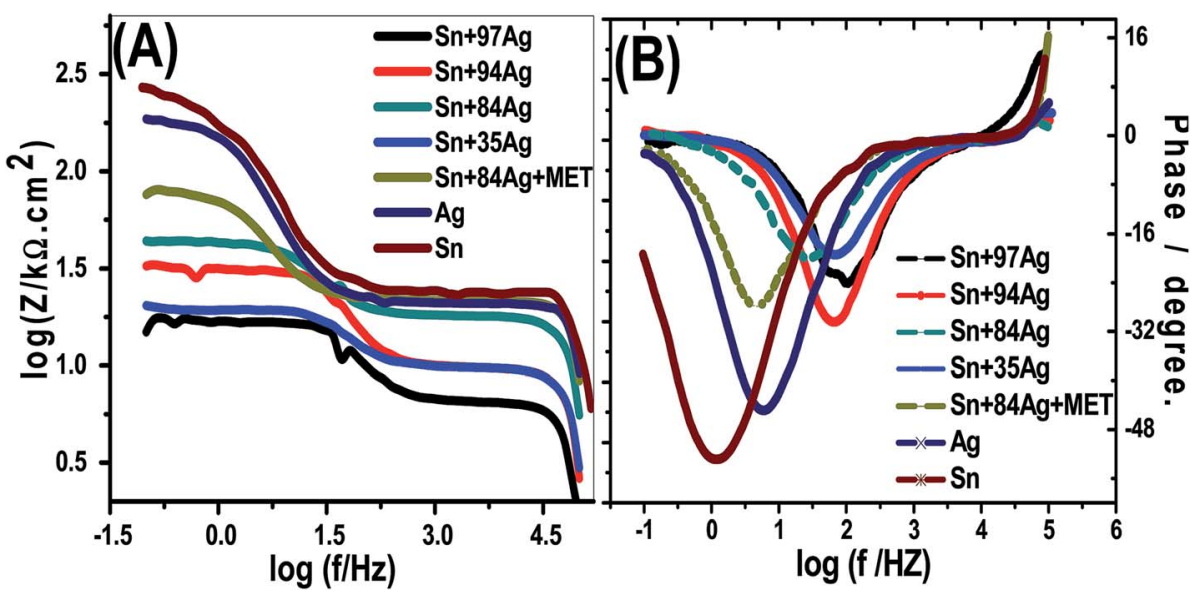

Fig. 11 Bode plots of the prepared alloys at the hydrogen evolution potential in $0.5 \mathrm{~mol} \mathrm{~L}^{-1} \mathrm{NaOH}$ stagnant naturally aerated aqueous solution at $25^{\circ} \mathrm{C}$; (A) the variation of the total impedance with frequency and (B) the variation of phase with frequency.

3.4.2. EC impedance spectroscopies (EISs). The measurements of the ECP are confirmed by EC impedance spectroscopies (EISs) measurements. The EISs are measured by combining galvanostat/potentiostat frequency analyzer with Voltalab 10 potentiostat (Radiometer PGZ100) and software Voltamaster 4. Fig. 10 and 11 present the EIS spectra (Nyquist plots and Bode plots) for the electroplated Sn, Ag, Sn-35Ag, Sn84Ag, Sn-84Ag with methionine, Sn-94Ag, and Sn-97Ag alloys at hydrogen evolution potentials. Fig. 10 shows faintly depressed capacitive semicircle shapes with different radii for the investigated cathodic electrodes. The sample with small radius has the ability to produce a large amount of hydrogen evolution than the sample with large radius. ${ }^{39,40}$ So that, both Sn-35Ag and Sn-97Ag alloys have a large amount of HER than other samples. ${ }^{40}$ To understand the EISs measurements thru hydrogen evolution, the obtained results are fitted to a simple equivalent circuit (Randle cell) which consist of a series combination of $R_{\mathrm{S}}$ (the solution resistance), with a parallel combination of two-layers capacitance, $C_{\mathrm{dl}}$, and the charge transfer resistance, $R_{\mathrm{ct}}$. The values of the equivalent circuit for each sample are recorded in Table 6.

The charge transfer process (CTP) is mainly used to regulate the HERs which is guaranteed by the uni-loop of Nyquist plots. The charge transfer resistance show higher values for the electroplated Sn, Ag, Sn-84Ag + methionine, Sn-84Ag, and Sn-94Ag alloys than that obtained by the electroplated Sn-35Ag and Sn-

Table 6 Values of the equivalent circuit from the fitting of the experimental impedance data that recorded for electrodeposited nanostructured $\mathrm{Sn}, \mathrm{Ag}, \mathrm{Sn}-\mathrm{Ag}$ alloys and methionine/Sn-Ag alloy in $1 \mathrm{~mol} \mathrm{~L}-1 \mathrm{NaOH}$ at $25^{\circ} \mathrm{C}$, based on the inset equivalent circuit in Fig. 9

\begin{tabular}{lccc}
\hline Alloys & $R_{\mathrm{s}} / \Omega \mathrm{cm}^{2}$ & $R_{\mathrm{ct}} / \Omega \mathrm{cm}^{2}$ & $C_{\mathrm{dl}} / \mathrm{mF} \mathrm{cm}^{-2}$ \\
\hline Sn-97Ag & 6.52 & 10.30 & 244 \\
Sn-94Ag & 9.88 & 21.40 & 234.9 \\
Sn-84Ag & 17.96 & 25.84 & 389.1 \\
Sn-35Ag & 9.85 & 10.93 & 418.2 \\
Sn-84Ag + Met & 32.93 & 56.99 & 44.11 \\
Ag-deposited & 21.54 & 56.91 & 109.9 \\
Sn-deposited & 20.04 & 163.5 & 486.5
\end{tabular}

97Ag alloys which supports the altered activities of the deposited electrodes during HERs. This could be ascribed to variation of morphologies and compositions of the electrodes. Furthermore, synergistic combination of $\mathrm{Ag}$ and $\mathrm{Sn}$ in addition to the porous structure of the surface improves HER kinetic. It can be seen that the electroplated $\mathrm{Sn}-35 \mathrm{Ag}$ and $\mathrm{Sn}-97 \mathrm{Ag}$ alloys are the most efficient electrocatalysts for HER. Fig. 11(A and B) shows Bode plots for the prepared alloys at the hydrogen evolution potential in $0.5 \mathrm{mo} \mathrm{lL}^{-1} \mathrm{NaOH}$ aqueous liquid at $25{ }^{\circ} \mathrm{C}$. Fig. 11(A) shows the variation of the total impedance with frequency and (B) the variation of phase with frequency. This figure shows resistive regimes at low and very high frequencies in addition to capacitive contribution in-between. The lowfrequency regime is correlated to the charge transfer resistance $\left(R_{\mathrm{ct}}\right)$ and the double-layered capacitance $\left(C_{\mathrm{dl}}\right)$ of the electrode. The very high-frequency regime may be related to the formation of a partially protective layer at the surface of the alloy cathode. ${ }^{41}$ The impedance of alloys with high $\mathrm{Ag} \%$ is decreased with increasing $\mathrm{Ag} \%$. The variation of phase with frequency is shown in Fig. 11(B). The maximum phase shift $\left(\theta_{\max }\right)$ is shifted to high frequencies by increasing $\mathrm{Ag} \%$ from $84 \%$ to $97 \%$. The $\theta_{\max }$ of alloys is located at higher frequencies than that of individual Sn or Ag electrode. Finally, the addition of methionine to Sn-84Ag shifts its $\theta_{\max }$ to low frequency.

\section{Conclusion}

This work showed the efficacious deposition of $\mathrm{Sn} / \mathrm{Ag}$ alloys from $1 \mathrm{ChCl}: 2$ EG DESs utilizing a real-time in situ technique. The prepared alloys were characterized by different investigative techniques. The gap between the reduction peaks of tin and silver was reduced by $114 \mathrm{mV}$ with the addition of $0.075 \mathrm{~mol} \mathrm{~L}^{-1}$ methionine, which facilitates the growth of $\mathrm{Ag}-\mathrm{Sn}$ alloys over a short time and low applied potential $(0.8 \mathrm{~V})$. Also, the height of the cathodic current peak increases with the gradual increase of $\mathrm{AgCl}$ concentration from 0.005 to $0.1 \mathrm{~mol} \mathrm{~L}^{-1}$. The preferred growth orientation of the single $\mathrm{Ag}_{3} \mathrm{Sn}$ phase (orthorhombic packed structure) was varied from (202) to (112) depending on $\mathrm{Ag} \%$, which accompanied a noticeable decrease of the 
dislocation density. EDX spectra proved the high purity of the prepared electrodes. The concentration of silver ions in ILs is the main factor which affects the crystallites sizes and morphologies of the $\mathrm{Ag} / \mathrm{Sn}$ alloys. The electrochemical properties of the prepared electrodes were studied toward HER by ECP and EIS measurements. The Sn-Ag alloys showed high catalytic activity for hydrogen production from $0.5 \mathrm{~mol} \mathrm{~L}^{-1} \mathrm{NaOH}$ solution. The electroplated $\mathrm{Sn}-35 \mathrm{Ag}$ and $\mathrm{Sn}-97 \mathrm{Ag}$ alloys are the most efficient electrocatalysts for HER, which correlated strongly with the observed morphologies and EIS measurements. Finally, the measured impedance values were closefitting to a hypothetical model for the electrode/electrolyte interface. The obtained data revealed that tin-silver alloys could be counted as good candidates for cathodic HERs with high throughput. Also, the simple growth of the designed Ag-Sn alloys and the strong demand for decorative finishes with enhanced corrosion resistance can extend their applications to many industrial areas.

\section{Conflicts of interest}

There are no conflicts to declare.

\section{References}

1 A. P. Abbott, A. I. Alhaji, K. S. Ryder, M. Horne and T. Rodopoulos, Electrodeposition of copper-tin alloys using deep eutectic solvents, Trans. IMF, 2016, 94, 113.

2 A. P. Abbott, G. Capper, K. J. McKenzie and K. S. Ryder, Electrodeposition of zinc-tin alloys from deep eutectic solvents based on choline chloride, J. Electroanal. Chem., 2007, 599, 288-294.

3 Electrodeposition from Ionic Liquids, ed. F. Endres, A. P. Abbott and D. R. MacFarlane, WILEY-VCH Verlag GmbH \& Co. KGaA, Weinheim, 2008, pp. 1-77.

4 S. Werner, M. Haumann and P. Wasserscheid, Ionic liquids in chemical engineering, Annu. Rev. Chem. Biomol. Eng., 2010, 1, 203-230.

5 A. P. Abbott, G. Capper, D. L. Davies, R. Rasheed and V. Tambyrajah, Novel solvent properties of choline chloride/urea mixtures, Chem. Commun., 2003, 70-71.

6 A. Gyozova, I. Krastev, L. Petkov and T. Dobrovolska, Electrodeposition and structure of binary alloys of silver, tin and antimony, Bulg. Chem. Commun., 2016, 48B, 103-109.

7 M. Negem and H. Nady, Electroplated Ni-Cu Nanocrystalline Alloys and their Electrocatalytic Activity for Hydrogen Generation using Alkaline Solutions, Int. J. Hydrogen Energy, 2017, 42, 28386-28396.

8 W. A. Badawy, H. Nady and M. Negem, Cathodic hydrogen evolution in acidic solutions using electrodeposited nanocrystalline NieCo cathodes, Int. J. Hydrogen Energy, 2014, 39, 10824-10832.

9 A. P. Abbott, S. Nandhra, S. Postlethwaite, E. L. Smith and K. S. Ryder, Electroless deposition of metallic silver from a choline chloride-based ionic liquid: a study using acoustic impedance spectroscopy, SEM and atomic force microscopy, Phys. Chem. Chem. Phys., 2007, 9, 3735-3743.
10 N. Pewnim and S. Roy, Electrodeposition of tin-rich $\mathrm{Cu}-\mathrm{Sn}$ alloys from a methanesulfonic acid Electrolyte, Electrochim. Acta, 2013, 90, 498-506.

$11 \mathrm{X} . \mathrm{H}$. Xu and C. L. Hussey, The electrochemistry of tin in the aluminum chloride-1-methyl-3-ethylimidazolium chloride molten salt, J. Electrochem. Soc., 1993, 140(3), 618-626.

12 C. T. J. Low and F. C. Walsh, Electrodeposition of tin, copper and tin-copper alloys from a methanesulfonic acid electrolyte containing a perfluorinated cationic surfactant, Surf. Coat. Technol., 2008, 202(8), 1339.

13 N. M. Martyak and R. Seefeldt, Additive-effects during plating in acid tin methanesulfonate electrolytes, Electrochim. Acta, 2004, 49, 4303.

14 C. S. Cha and Y. B. Zu, Behavior of perfluorinated surfactants at the electrode/solution interface, Langmuir, 1998, 14(21), 6280.

15 S. Roy, M. Matlosz and D. Landolt, Effect of corrosion on the composition of pulse plated $\mathrm{Cu}-\mathrm{Ni}$ alloys, J. Electrochem. Soc., 1994, 141, 1509.

16 S. Roy, Electrodeposition of compositionally modulated alloys by an electrodeposition-displacement reaction method, Surf. Coat. Technol., 1998, 105, 202.

17 S.-Z. Kure-Chu, T. Ogasawara, R.-B. Ye, H. Yashiro and K. Sasaki, Thermal Stability and Sulfidizing Resistance of High Reflective Multilayered $\mathrm{Sn} / \mathrm{Ag}_{3} \mathrm{Sn}$ and $\mathrm{Sn} / \mathrm{Ag}$ Films, Electrochim. Acta, 2016, 212, 380-389.

18 Y. Qin, G. D. Wilcox and C. Liu, Electrodeposition and Characterization of Eutectic Sn-Ag Alloy as Solder Bumps for Flip-Chip Interconnection, J. Electrochem. Soc., 2009, 156(10), D424-D430.

19 S. Arai, H. Akatsuka and N. Kaneko, Sn-Ag Solder Bump Formation for Flip-Chip Bonding by Electroplating, $J$. Electrochem. Soc., 2003, 150(10), C730-C734.

20 A. Christensen, A. Ruban, P. Stoltze, K. W. Jacobsen, H. L. Skriver, J. K. Nørskov and F. Besenbacher, Phase diagrams for surface alloys, Phys. Rev. B, 1997, 56(10), 5822-5834.

21 D. Yin, K. Kuczera and T. C. Squier, The sensitivity of carboxyl-terminal methionines in calmodulin isoforms to oxidation by $\mathrm{H}_{2} \mathrm{O}_{2}$ modulates the ability to activate the plasma membrane Ca-ATPase, Chem. Res. Toxicol., 2000, 13, 103-110.

22 D. J. Bigelow and T. C. Squier, Redox modulation of cellular signaling and metabolism through reversible oxidation of methionine sensors in calcium regulatory proteins, Biochim. Biophys. Acta, 2005, 1703(2), 121-134.

23 M. P. Ferla and W. M. Patrick, Bacterial methionine biosynthesis, Microbiology, 2014, 160, 1571-1584.

24 X. Li, W. Li, S. Yang and L. Hou, Using methionine as an environment-friendly corrosion inhibitor for copper-nickel alloy in a chloride solution, Mater. Express, 2017, 7(6), 480490.

25 H. Nakano, S. Oue1, M. Uranaka and M. Masuda, Electrodeposition of $\mathrm{Sn}-\mathrm{Ag}$ Alloys and Evaluation of Connection Reliability for Automotive Connectors, Mater. Trans., 2010, 51(4), 712-719. 
26 M. Shaban, M. Zayed and H. Hamdy, Preparation and characterization of nanostructured $\mathrm{ZnO}$ thin films for selfcleaning applications, RSC Adv., 2017, 7, 617-631.

27 M. Shaban, M. Mustafa and A. M El Sayed, Structural, optical, and photocatalytic properties of the spray deposited nanoporous CdS thin films; influence of copper doping, annealing, and deposition parameters, Mater. Sci. Semicond. Process., 2016, 56, 329-343.

28 M. Shaban, M. Ali, K. Abdelhady and H. Hamdy, $\mathrm{Al}_{2} \mathrm{O}_{3}$ and $\mathrm{Sn} / \mathrm{Al}_{2} \mathrm{O}_{3}$ nanowires: Fabrication and Characterization, Micro Nano Lett., 2015, 10(7), 324-329.

29 A. Sharma, Y. J. Jang and J. P. Jung, Effect of current density on morphology of electroplated tin, Surf. Eng., 2015, 31(6), 458-464.

30 M. A. Oliver-Tolentino, E. M. Arce-Estrada, C. A. CortesEscobedo, A. M. Bolarin-Miro, F. S. D. Jesus, R. G. Gonzalez-Huerta, et al., Electrochemical behavior of NixW1_x materials as catalyst for hydrogen evolution reaction in alkaline media, J. Alloys Compd., 2012, 536, 245-249.

31 S. Papadimitriou, A. Tegou, E. Pavlidou, S. Armyanov, E. Valova, G. Kokkinidis, et al., Preparation and characterization of platinum- and gold-coated copper, iron, cobalt and nickel deposits on glassy carbon substrates, Electrochim. Acta, 2008, 53, 6559-6567.

32 F. Rosalbino, D. Maccio, E. Angelini, A. Saccone and S. Delfino, Electrocatalytic properties of Fe-R $\left(\mathrm{R} \frac{1}{4}\right.$ rare earth metal) crystalline alloys as hydrogen electrodes in alkaline water electrolysis, J. Alloys Compd., 2005, 403, 275-282.

33 E. Navvaro-Flores, Z. Chong and S. Omanovic, Characterization of $\mathrm{Ni}$, NiMo, NiW and NiFe electroactive coatings as electrocatalysts for hydrogen evolution in an acidic medium, J. Mol. Catal. A: Chem., 2005, 226(2), 179197.

34 M. Zayed, A. M. Ahmed and M. Shaban, Synthesis and characterization of nanoporous $\mathrm{ZnO}$ and $\mathrm{Pt} / \mathrm{ZnO}$ thin films for dye degradation and water splitting applications, Int. J. Hydrogen Energy, 2019, 44(33), 17630-17648.

35 W. A. Badawy, H. E. Feky, N. H. Helal and H. H. Mohammed, Cathodic hydrogen evolution on molybdenum in $\mathrm{NaOH}$ solutions, Int. J. Hydrogen Energy, 2013, 38, 9625-9632.

36 B. Neveu, F. Lallemand, G. Poupon and Z. Mekhalif, Electrodeposition of $\mathrm{Pb}$-free $\mathrm{Sn}$ alloys in pulsed current, Appl. Surf. Sci., 2006, 252, 3561-3573.

37 M. A. Garcia-Contreras, S. M. Fernandez-Valverde and J. R. Vargas-Garcia, Pt, PtNi and PtCoNi film electrocatalysts prepared by chemical vapor deposition for the oxygen reduction reaction in $0.5 \mathrm{M} \mathrm{KOH}, J$. Alloys Compd., 2010, 504, 425-428.

38 M.-H. Shao, J. H. Odell, S. Choi and Y. Xia, Electrochemical surface area measurements of platinum- and palladiumbased nanoparticles, Electrochem. Commun., 2013, 31, 46-48.

39 M. Rabia, M. Shaban, A. Adel and A. A. Abdel-Khaliek, Effect of Plasmonic Au Nanoparticles on the Photoactivity of Polyaniline/Indium Tin Oxide Electrodes for Water Splitting, Environ. Prog. Sustainable Energy, 2019, DOI: 10.1002/ep.13171.

40 W. A. Badawy, H. Nady and G. M. Abd El-Hafez, Electrodeposited $\mathrm{Zn}-\mathrm{Ni}$ alloys as promising catalysts for hydrogen production-preparation, characterization and electro-catalytic activity, J. Alloys Compd., 2017, 699C, 11461156.

41 N. H. Helal, Corrosion inhibition and adsorption behavior of methionine on Mg- Al-Zn alloy, J. Chem. Eng. Mater. Sci., 2011, 2(2), 28-38. 